\title{
Structural Relationship of Learning Environment, Learning Approaches, and Generic Skills among Engineering Students
}

\author{
Saemah Rahman ${ }^{1} \&$ Seri Bunian Mokhtar ${ }^{2}$ \\ ${ }^{1}$ Faculty of Education, Universiti Kebangsaan Malaysia, Malaysia \\ ${ }^{2}$ Department of Civil Engineering, Sultan Azlan Shah Polytechnic, Malaysia \\ Correspondence: Saemah Rahman, Faculty of Education, Universiti Kebangsaan Malaysia, Malaysia. Tel: \\ 60-19-272-9290. E-mail: saemahukm@yahoo.com
}

Received: July 3, 2012 Accepted: August 15, 2012 Online Published: October 26, 2012

doi:10.5539/ass.v8n13p280

URL: http://dx.doi.org/10.5539/ass.v8n13p280

\begin{abstract}
This study evaluated structural relationships among learning environment, learning approaches, and generic skills of engineering students. Research instruments used were: (i) an adapted Course Experience Questionnaire (CEQ), (ii) the Revised Two-Factor Study Process Questionnaire (R-SPQ-2F), and (iii) a Generic Skills Instrument. Participants were 527 engineering students in eight Malaysian technical institutions. The structural equation model (SEM) was tested using SPSS 17 and AMOS 18 software. Two learning environment elements namely learning community and assessment were shown to have a direct relationship, and three other elements (clear objective, good teaching and learning resources) were indirectly related to generic skills through learning approach. A model of inter-relationship between generic skills (GS), learning approaches (LA) and learning environment (LE) was proposed.
\end{abstract}

Keywords: generic skills, learning environment, learning approaches, structural equation model, engineering students

\section{Introducation}

Many employers expressed dissatisfaction over the quality of graduates that enters the job market. The issue of graduates employability and its association with lack of generic skills has become an important issue in Malaysia The study done in Malaysia showed that the development of generic skills among students at higher learning institutions still needs improvement (Aida Suraya Md Yunus, Rosini Abu, Sharipah Mohd Nor, Rohani Ahmad Tarmizi, Kamariah Abu Bakar, Wan Zah Wan Ali, Ramlah Hamzah \& Habsah Ismail, 2005; Roselina Shakir, 2009; Noor Dayana Abd Halim, 2010; Ruhizan M. Yasin, Saemah Rahman, Ramlee Mustapha \& Kamarudin Tahir, 2011). In accordance with these predicaments, education institutions are urged to intensify efforts to improve the quality of the graduates, particularly in terms of generic skills that are required in the workplace. Thus, it is very important to identify factors that can be associated with the development of generic skills among students.

Social cognitive theory proposes a relationship between environmental factors, individual personal factors, and individual behaviour (Bandura 1986). Based on this theory, it is hypothesised that students' generic skills result from their interaction with their environments. This hypothesis is consistent with human ecology theory (Bronfenbrenner, 1979) that describes the influence of the environment on individual development. In the context of learning, this hypothesis can be explained using Biggs 3P learning model (1999). This model addresses the relationship between learning environments, learning approaches, and learning outcomes. A vast body of existing literature has established the importance of the learning environment as a factor influencing student learning and achievement. Studies on learning approaches suggest that students' adoption of deep-learning or surface learning approaches is contingent on their experience of interacting with the learning environment. Moreover, it is suggested that learning approaches play a mediator role in predicting learning outcome (Goh, 2005; Lizzio, Wilson, \& Simons, 2002). The relationship between the learning environment and learning outcome (generic skills) was also supported by Kember and Leung (2005), who found that the learning environment has a significant impact on the development of students' generic skills. This study aimed to identify the relationship between learning environment factors and learning approach as related to the development of students' generic skills. 


\subsection{Learning Environment, Learning Approaches, and Generic Skills}

The influence of a learning environment is seen as the quality of teaching and learning in the context in which it occurs (Ramsden 1991, Biggs 1999). A study by Ramsden (1979) identified eight dimensions of the learning environment: (i) student interaction, (ii) commitment in teaching, (iii) work-load, (iv) teaching methods, (v) career relevance, (vi) clear goals, (vii) the social atmosphere and (viii) the freedom to learn. Ramsden (1991) then categorised the learning environment factors that can affect learning outcomes into five dimensions: (i) assessments, (ii) work-load, (iii) good teaching, (iv) independent learning, and (v) clear objectives. The study of learning environment factors was then expanded by Wilson, Lizzio and Ramsden (1997) who added the construct of generic skills into the Course Experience Questionnaire (CEQ). McInnis, Griffin, James and Coates (2001) added optional scales to the CEQ that included: (i) student support, (ii) graduate qualities, (iii) intellectual motivation, (iv) learning communities, and (v) learning resources. Further, Lizzio et al. (2002) listed assessment, workload, good teaching, independent learning, and clear objectives as the learning environment constructs in their study. In addition, the exploratory factor analysis conducted by Goh (2005) reported that learning environment consists of three factors: (i) assessment, (ii) good teaching, and (iii) clear objectives. A total of six factors were selected as learning environment factors, and the component of generic skills was identified from the literature.

Past studies showed that learning environment factors such as clear objectives, assessments, work-load, good teaching and teaching approaches influenced learning outcomes through learning approaches as the mediator (Entwistle \& Ramsden 1983; Lizzio et al., 2002; Ramsden, 1992; Diseth, Pallesen, Horland \& Larsen 2006). Other studies reported that learning resources and learning community are components of the learning environment that affect students' generic skills (Smith \& Bath, 2006; Kamaruddin, 2010; Norlia, 2006).

Meanwhile, studies on learning approaches suggested the relationship between learning approaches and generic skills (Lizzio et al., 2002; Goh 2005; Ryan, Irwin, Bannon, Mulholland \& Baird 2004). Learning approaches refer to how students deal with academic tasks in a learning environment. According to Biggs and Tang (2007), learning approaches describe how students learn in different learning environments. Learning approaches can serves as an indicator of the quality of learning and it is proposed that the adoption of different approaches has an impact on students' learning outcomes. It has been suggested that compared to surface-learning approaches, the use of deep learning approaches is related to higher learning outcomes (Marton \& Saljo, 1976; Biggs \& Tang, 2007).

A review of the literature also revealed that there is a relationship between learning environment factors and learning approaches. Previous studies found that work-load (a construct in learning environment) has a positive relationship with the surface-learning approach and a negative relationship with the deep-learning approach (Kember \& Leung, 1998; Lizzio et al., 2002; Karagiannopoulou \& Christodoulides, 2005). These findings suggested that if the workload is perceived as heavy, students tend to adopt surface-learning approach. Meanwhile, if the workload is considered reasonable students are more inclined to adopt deep-learning approach.

Studies on other learning environment factors such as assessment (Gijbels \& Dochy 2006; Kember, Leung \& Ma 2007; Karagiannopoulou \& Christodoulides 2005) and good teaching (Ramsden, Prosser, Trigwell \& Martin 2007; Cabrera, Colbeck \& Terenzini 2001; Karagiannopoulou \& Christodoulides 2005) were also found to have a negative relationship with the surface-learning approach and a positive relationship with the deep-learning approach. These relationships showed that assessment also play a key role in determining what learning approach will be adopted by the students. If assessments are perceived as emphasized more on the importance of what they have memorized as compared to what they have understood, the students will be encouraged to adopt surface-learning approach rather than deep-learning approach.

A study by Lizzio et al. (2002) also found that there are direct and indirect relationships between the learning environment and generic skills through learning approaches. This study was supported by Ryan et al., 2004), who reported similar research findings. Based on these studies, it is suggested that learning environment has direct and indirect relationships with generic skills through learning approaches.

Thus, it can be concluded that there is an evident to associate the relationships between learning environment, learning approaches, and students' generic skills. Since the current trend in education focuses on the development of students' generic skills, it is important to identify how these two constructs, namely, the learning environment and learning approaches, can be predicted so that effort can be directed toward supporting the development of students' generic skills. Although past research has dealt with these issues (i.e. Goh 2005; Lizzio et al., 2002), no study has been conducted in Malaysia involving students in a technical learning environment. Therefore, this study aimed to develop a model that can explain how learning environment, learning approaches, 
and learning outcomes are related, both directly and indirectly in Malaysian context.

In this study, learning environment factors and components of generic skills were identified from the literature. A total of six factors for the learning environment construct and ten components of generic skills were included in the model together with two types of learning approaches, the deep-learning and the surface-learning approaches. It is expected that learning environment factors will influence the adoption of learning approaches, which in turn will affect the development of students' generic skills. The relationship between the constructs was tested on a large sample of engineering students, using the structural equation model (SEM) technique. This statistical technique enabled us to estimate the relative contribution of the variables involved and to study the nature of their interactions. SEM makes it possible to test whether theoretically plausible models provide a good fit to the data.

\section{Method}

\subsection{Sample}

Study participants were engineering students from eight technical institutions in Malaysia. The participants were selected using stratified random sampling. A total of 600 questionnaires were administered, and 527 (337 males and 190 females) were used in the final analysis. Samples exceeding 500 subjects are adequate for analysis using the SEM technique (Hair, Anderson, Tathan, \& Black, 2006). The participants were given as much time as they needed to complete the questionnaires, and they completed it in about 35 to 45 minutes.

\subsection{Instruments}

This study used a questionnaire that consists of four parts. Part A contains demographic information. Part B contains 20 items measuring learning approaches (LA) adapted from the Revised Two-Factor Study Process Questionnaire (R-SPQ-2F) (Biggs, Kember \& Leung, 2001). Part C contains the learning environment factors (LE) adapted from the Course Experience Questionnaire (CEQ) and What Is Happening in the Classroom (WIHIC) (Ramsden, 1991; McInnis, Griffin, James, \& Coates, 2001; Dorman, 2003). Part D contains 55 items on generic skills (GS) and was adapted from a questionnaire developed by the Secretary's Commission on Achieving Necessary Skills (SCANS, 2001), learning outcomes domains from Malaysian Qualifications Agency (2007), Mohd Sattar (2008), Kamarudin Tahir (2010), and components of Soft Skills from Ministry of Higher Education, Malaysia (KPTM 2006).

There is psychometric support for the three instruments that measure the constructs addressed in this research. In order to assess the internal consistency of variables, a reliability scale test was carried out. The internal consistency value, Cronbach's Alpha, was above 0.5 for all variables, which is a satisfactory reliability value. According to Babbie (1992), the value of Cronbach's Alpha is classified based on a reliability index in which $0.90-1.00$ is very high, $0.70-0.89$ is high, $0.30-0.69$ is moderate, and $0.00-0.30$ is low. The Cronbach's Alpha values for the instruments in this study were above 0.70 , indicating high or very high reliability.

Further, confirmation factor analysis (CFA) was performed to examine the underlying relationship among the set of indicators. This analysis sought support for the six learning environment factors (LE), two learning approach constructs (LA) and ten generic skills components (GS). Maximum likelihood estimation was used to generate an estimated full-fledged measurement model. Maximum likelihood was selected because it is a robust estimation method capable of handling large samples and distributions that depart from normality (Arbuckle, 1997). The measurement model consists of the indicators for each construct. All latent constructs (LA, LE, and GS) are permitted to correlate with each other. Model fit was evaluated using the fit indices. Individual parameter estimates were tested using critical ratios.

Assessment of model fit was based on multiple criteria including both absolute misfit and relative fit indices. The absolute misfit indices included the root mean square error of approximation (RMSEA) (Hair et al., 2006) and the relative goodness-of-fit indices used in the study were the comparative fit index (CFI), Tucker Lewis index (TLI) and incremental-fit-index (IFI) (Hair et al., 2006). Arbuckle (1997) and Arbuckle \& Wothke (1999) states that a model is fit when the index shows that (i) the value of CMIN/df is between 1 and 5, considered acceptable or acceptable fit between model and data, (ii) indices of CFI and TLI approach 1.00, and (iii) the RMSEA index of 0.08 or less indicates a reasonable error and can be accepted.

The assessment of fit (overall fit) for the GS, LA, and LE model shows that it fits and can be accepted based on the indicators suggested by Hair et al., (2006). For the generic skills (GS) model, the degrees of freedom index, $(\mathrm{CMIN} / \mathrm{df}=1.938, \mathrm{CFI}=0.932, \mathrm{TLI}=0.930, \mathrm{IFI}=0.938$, and $\mathrm{RMSEA}=0.042$. These values indicate that data from the sample of 527 students fit this model. For the learning approaches (LA) model, the degrees of freedom index, $\mathrm{CMIN} / \mathrm{df}=3.174, \mathrm{CFI}=0.949, \mathrm{TLI}=0.935, \mathrm{IFI}=0.949$, and $\mathrm{RMSEA}=0.064$, indicating that data from 
the sample also fit this model. The value of degrees of freedom index, CMIN $/ \mathrm{df}=1.998, \mathrm{CFI}=0.945, \mathrm{TLI}=$ 0.935 , IFI $=0.945$, and RMSEA $=0.044$, indicate that data from the sample fit the learning environment (LE) model.

Convergent validity was also evaluated based on the coefficients of each item, the reliability of the constructs and the average variance extracted for a latent variable (Anderson \& Gerbing, 1988; Fornell \& Larcker, 1981). The analysis showed that the lowest construct's reliability value was greater than 0.70 and that the variance extracted 0.30 to 0.55 . Discriminant validity was evaluated by comparing the squared correlations between the two constructs and the average variance extracted. If the average variance extracted exceeds the squared correlation, discriminant validity is achieved (Hair et al., 2006). The value of the variance extracted for all constructs was greater than the squared correlation between the two constructs. The results of this analysis show that convergent validity and discriminant validity were achieved.

\section{Results}

The overarching goal of this research was to test the structural equation model (SEM) describing the two main latent variables (LE and LA), as they relate to students' generic skills. Two components were used in this inquiry: a measurement model and a structural model (Hair et al., 2006). The measurement model addresses issues of validity and reliability, and the structural model tests the hypothesized relationship among the constructs. The first step was to build the measurement model based on the confirmatory factor analysis (CFA) for all the variables in this study, and the second step was to build the SEM of the latent variables. Results of this study is presented in five sub-sections namely: i) Measurement model, ii) Structural model, iii) Indirect relationship, iv) Predictor for process factor, and v) Predictor for product factor.

\subsection{Measurement Model}

This study employs confirmation factor analysis (CFA) to measure the goodness-of-fit of the measurement models. CFA is a multivariate statistical approach to test and validate a hypothesized measurement model. A measurement model is statistically valid if its observed variables are significantly related to latent variables (factors) underpinning that measure. The results indicated that the degrees of freedom index was less than 5 $(\mathrm{CMIN} / \mathrm{df}=1.717)$, the RMSEA $=0.037$, is less than 0.08 and that CFI, TLI, and IFI were all above $0.9(0.930$, 0.923 , and 0.931 respectively; thus, the model-fit is admissible. This result means that there is no significant difference between the proposed model and observed model, indicating that data from the sample fit with the model.

\subsection{Structural Equation Model}

Figure 1 shows the standardised parameter of the structural model depicting the relationship between six LE factors, two LA factors and ten GS components. The AMOS statistical estimates results revealed that the degrees of freedom index was less than $5(\mathrm{CMIN} / \mathrm{df}=1.717)$. The values of CFI, TLI, and IFI $(0930,0.923$, and 0.931 respectively) were all above 0.9 and the RMSEA (0.037) was less than 0.08 . These statistical estimates showed that the hypothesised model fulfilled the model fit indicators employed in this study based on the indicators recommended by Arbuckle (1997); Arbuckle and Wothke (1999); and Hair et al., (2006). This result indicated that data from the sample fit with the model. 


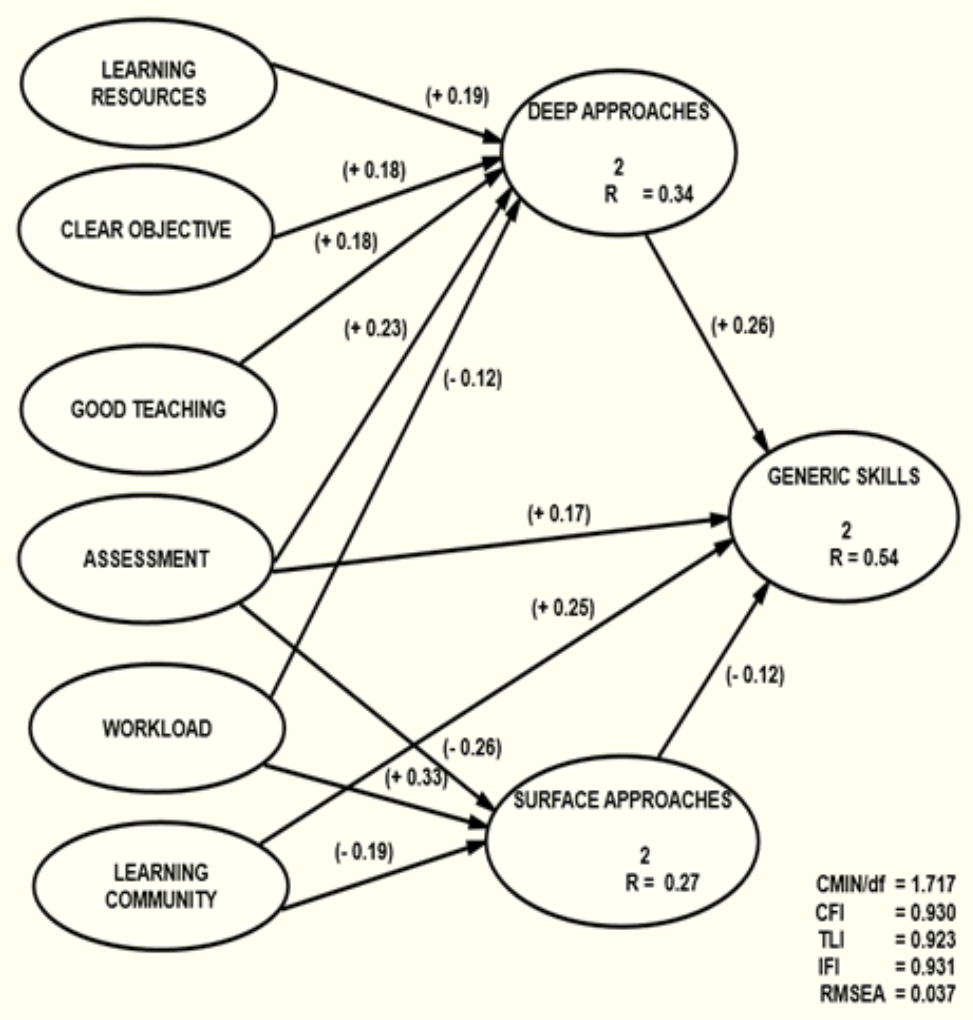

Figure 1. Structural equation model for GS, LA, and LE

The parameter estimates of the model showed that all of the paths between the latent variables were statistically significant except the eight paths for which the null hypotheses were accepted, as shown in Table 1. Three relationship paths can be concluded: (i) The relationship between learning environment factors and learning approaches revealed that clear objectives, assessment, good teaching, and learning resources showed a significant positive relationship with the deep-learning approach. Meanwhile, work-load showed a positive relationship with the surface-learning approach, whereas assessment appears to be negatively related to surface-learning approach; (ii) The relationship between learning approach and generic skills showed that a deep-learning approach have a positive relationship with students' generic skills, whereas a surface-learning approach showed a negative relationship with generic skills, (iii) The relationship between learning environment factors and generic skills revealed only two of the learning environment factors were significantly related to generic skills, assessment and learning community.

Table 1. Path coefficients and hypothesis test

\begin{tabular}{|c|c|c|c|c|c|c|}
\hline Hypotheses & Variable Relationship & & & P Value & Coefficient & H null \\
\hline 1 & deep approaches & $<--$ & clear objectives & $.016^{*}$ & .183 & Rejected \\
\hline 2 & deep approaches & $<--$ & assessment & $* * *$ & .231 & Rejected \\
\hline 3 & deep approaches & $<---$ & learning community & .557 & -.043 & Accepted \\
\hline 4 & deep approaches & $<--$ & good teaching & $.022 *$ & .180 & Rejected \\
\hline 5 & deep approaches & $<--$ & learning resources & $.018 *$ & .185 & Rejected \\
\hline 6 & deep approaches & $<--$ & workload & $.032 *$ & -.117 & Rejected \\
\hline 7 & surface approaches & $<---$ & clear objectives & .700 & .025 & Accepted \\
\hline 8 & surface approaches & $<--$ & assessment & $* * *$ & -.277 & Rejected \\
\hline 9 & surface approaches & $<--$ & learning community & $.003 *$ & -.194 & Rejected \\
\hline 10 & surface approaches & $<---$ & good teaching & .261 & -.074 & Accepted \\
\hline
\end{tabular}




$\begin{array}{lllllll}11 & \text { surface approaches } & <--- & \text { learning resources } & .088 & .114 & \text { Accepted } \\ 12 & \text { surface approaches } & <--- & \text { workload } & * * * & \mathbf{. 3 3 0} & \text { Rejected } \\ 13 & \text { generic skills } & <--- & \text { deep approaches } & * * * & \mathbf{. 2 5 9} & \text { Rejected } \\ 14 & \text { generic skills } & <--- & \text { surface approaches } & \mathbf{. 0 1 0} & \mathbf{- . 1 1 9} & \text { Rejected } \\ 15 & \text { generic skills } & <--- & \text { clear objectives } & .138 & .082 & \text { Accepted } \\ 16 & \text { generic skills } & <-- & \text { assessment } & \mathbf{. 0 0 1 *} & \mathbf{. 1 6 8} & \text { Rejected } \\ 17 & \text { generic skills } & <--- & \text { learning community } & * * * & . \mathbf{2 4 8} & \text { Rejected } \\ 18 & \text { generic skills } & <--- & \text { good teaching } & .152 & .081 & \text { Accepted } \\ 19 & \text { generic skills } & <--- & \text { learning resources } & .061 & .109 & \text { Accepted } \\ 20 & \text { generic skills } & <--- & \text { workload } & .397 & .037 & \text { Accepted }\end{array}$

Note: $* p<0.05 ; * * p<0.01 ; * * * p<0.001$.

\subsection{Indirect Relationship}

This discussion of indirect relationships with generic skills covers four LE factors: clear objectives, learning resources, assessment, and good teaching as only these variables proved to have an indirect relationship with generic skills after learning approach variables were included in the model. As seen in Table 2, the assessment variable $(\mathrm{r}=0.093)$ was found to have the greatest indirect value, followed by the good teaching variable $(\mathrm{r}=$ $0.055)$, clear objectives $(r=0.045)$, and learning resources $(r=0.034)$. Therefore, it can be concluded that the assessment, learning resources, clear objectives, and good teaching variables have an indirect relationship with generic skills through learning approaches.

Table 2. Indirect relationship between clear objectives, learning resources, good teaching and assessment with generic skills

\begin{tabular}{ll}
\hline Variables & Indirect Relationship \\
\hline Good Teaching & .055 \\
Learning Resources & .034 \\
Clear Objectives & .045 \\
Assessment & .093 \\
\hline
\end{tabular}

3.4 Predictor Variables (LE) for Process Factor (LA)

The results of structural equation model were used to determine if the predictor variables (learning environment) can explain the variations in learning approach. This refers to the overall contribution of the model on learning approach that can be assessed with the value of 'squared multiple correlation' $\left(\mathrm{R}^{2}\right)$ in structural equation model. The value of $\mathrm{R}^{2}$ indicates the percentage of variance that can be explained by the variables. Based on the results of the structural equation model, the value of $\mathrm{R}^{2}$ for the deep-learning approach is 0.34 . This indicates that the contribution of all the variables associated with the deep-learning approach in the model is $34 \%$. To measure the significance of this model in practical terms, we need to examine its effect size. In terms of effect size, according to Cohen (1988), $\mathrm{R}^{2}$ values less than 0.01 are considered small, 0.09 is considered moderate, and 0.25 is considered significant. Therefore, in interpreting this study, the effect size of 0.34 is significant and large.

Based on the results of the structural equation model, the value of $\mathrm{R}^{2}$ for the surface-learning approach is 0.27 . This indicates that the contribution of all the variables associated with the surface-learning approach in the model is $27 \%$. In practical terms, the effect size of 0.27 is considered significant and large.

\subsection{Predictor Variables for Product Factor (GS)}

Based on the results of the structural equation model, the value of $\mathrm{R}^{2}$ for generic skills is 0.54 . This indicates that the contribution of all the variables associated with generic skills in the model is $54 \%$. In terms of effect size, 0.54 is considered significant and large.

The results also revealed four of the predictor variables that contributed significantly to the variation in generic skills, which were deep-learning approach, surface-learning approach, learning community, and assessment. Clear objectives, learning resources, and good teaching are indirect predictors for generic skills through the learning approach. The relationship between work-load and generic skills was not significant. The largest predictor variable was the deep-learning approach followed by learning communities, assessment, and negative surface-learning approaches. Learning resources, clear objectives and good teaching have an indirect influence on the development of generic skills. 


\section{Discussion}

The findings of this study support the hypothesised relationships between learning environment and students' learning behaviour as suggested by social cognitive theory (Bandura 1986), the theory of human ecology (Bronfenbrenner, 1979) and Biggs 3P model of learning (1999). The study found that two elements of the learning environment, that is learning community and assessment, have a direct relationship with generic skills. Three other elements of the learning environment, that is clear objectives, learning resources, and good teaching, are indirectly related to generic skills through learning approach. The existence of direct and indirect relationships is consistent with Biggs' learning model, which was used to form the basis of the relationships between the variables in this study.

The learning environment factors for this study were assessment, clear objectives, workload, learning community, learning resources and good teaching. The elements of the learning approach are the deep and surface learning approaches. This analysis showed that of the six elements of the learning environment, three elements have a relationship with the surface-learning approach and five elements have a relationship with the deep-learning approach. The results of this study showed that clear objectives, assessment, good teaching, and learning resources have a positive relationship with the deep-learning approach; and that work-load has a significant negative relationship with the deep-learning approach. Moreover, work-load has a positive relationship with the surface-learning approach, but learning community and assessment have a negative relationship with the surface-learning approach. This study supported previous studies by Lizzio et al. (2002), Goh (2005), Kember and Leung (1998), Karagiannopoulou and Christodoulides (2005), Gijbels and Dochy (2006), Kember, Leung and $\mathrm{Ma}$ (2007) and Ramsden, Prosser, Trigwell and Martin (2007).

This study also supports work done by Lizzio et al. (2002), Goh (2005), and Ryan et al. (2004), who similarly reported that learning approaches lead to different learning outcomes, deep-learning approaches are positively related to generic skills, and surface-learning approaches have a negative relationship with generic skills. This study also supports the learning approach theory, which proposes that learning approaches lead to different learning outcomes. Studies have reported that compared to surface-learning approaches, the use of a deep-learning approach is associated with higher learning outcomes (Marton \& Saljo, 1976).

This study also consistent with work done by Ryan et al (2004) and Lizzio et al. (2002), who reported similar research findings suggesting that learning environment has direct and indirect relationships with generic skills through learning approaches. This means that students who viewed their learning environment positively will tend to use deep-learning approaches rather than surface-learning approaches in handling their academic tasks. In doing so, students use a variety of skills that lead to better development of generic skills.

A final but important question refers to the practical implications of this study. If we wish to influence students' generic skills, is it worthwhile to invest in optimising the learning environment and the manner in which students tackle study tasks. The first implication concerns the effect of the learning environment upon learning. Given that students' perceptions of the learning environment seem to influence their learning approach, deep-learning could be enhanced by improving the quality of various components of the learning environment, and at the same time, supporting the development of students' generic skills. As indicated by this study, learning environment also plays both direct and indirect roles. For educationists, this suggests that supporting students' learning also involves helping them reflect on the opportunities and threats they face when studying in learning environments that are designed to enhance deep learning. An analysis of the relationships established in this research suggests that all components of learning environments play a role in explaining the variance in the adoption of learning approaches among students. Perceptions of students towards the components of the learning environment will influence their approach to learning which eventually will affect the development of their generic skills. It can be concluded that learning approach is a mediator between the learning environment and the development of generic skills.

Despite several limitations, results from the present study do offer significant new insights and extend our existing knowledge in this emerging area of student learning. The present findings add to the body of research by documenting the precise interactions between learning environment and student learning approaches in predicting a generic skill. Since our findings provide convincing evidence regarding the importance of both learning environment and student learning approaches in predicting generic skills, educators need to pay attention to these two dynamic aspects of student learning from pedagogical and instructional design perspectives. Furthermore, continuous monitoring of student learning experience, possibly via the use of appropriate good teaching and workload, authentic assessments or group studies/activities, is also encouraged in the review of programme design and teaching practices. 
It is therefore necessary to investigate current practices in teaching engineering subjects and to implement improvements to encourage students to develop imaginative, flexible, and adaptive skills that can only be properly established by adopting a deep approach to learning. A starting point is to consider areas of the teaching context in which there is a significant correlation between students' perceptions and their approaches to learning. Good teaching, appropriate assessment, learning resources, and clear goals are positively correlated with a deep approach to learning. Improvement in these areas may encourage students to adopt a deep approach. Conversely, there is a significant negative correlation between a surface approach and both assessment and learning community, which indicates that improvement in these two areas of the teaching context may encourage students to be less inclined to adopt a surface approach.

Ramsden (1992) suggests that it is not possible to train students to adopt deep approaches when the educational environments give them the message that surface approaches are rewarded. In other words, unsuitable assessment procedures may put pressure on students to take the wrong approach to learning tasks. Engineering educators should ensure that assessment procedures are appropriate. Clear goals and standards allow students to know where they are headed and encourage them to take responsibility for their own learning. Engineering educators should ensure that it is made clear to students what is expected of them in the course.

This study provides evidence that students' approaches to learning in an engineering subject are related to their perceptions of the learning environment. As such, it highlights various aspects of the learning environment that might be enhanced so as to help improve students' approaches to learning. As positive changes are made, it is expected that they will be reflected in the adoption of deep approaches to learning and result in better outcomes in terms of generic skills.

\section{Conclusion}

In conclusion, a model is proposed based on the direct and indirect relationships between the learning environment, learning approach, and generic skills. This proposed model represents the processes involved to enhance the development of generic skills through these variables. The final model that depicts the interrelationships between the variables is shown in Figure 2. Arrows indicate the direction of the relationship, the positive sign $(+)$ indicates a positive relationship and a negative sign (-) indicates a negative relationship.

Based on this figure, students should be encouraged to adopt a deep-learning approach rather than surface-learning approach in order to produce a high level of generic skills development. To encourage students to practice a deep-learning approach, the related variables of the learning environment should be controlled. A positive environment could encourage deep learning that further enhances the students' generic skills.

The model clearly illustrates the importance of the relationship between learning environment and learning approaches in the development of students' generic skills. Therefore, it can be concluded that efforts to improve the practice of a deep-learning approach among polytechnic students must be supported by giving adequate emphasis to learning environment factors. This will encourage students to apply a deep-learning approach and improve the quality of their generic skills. 


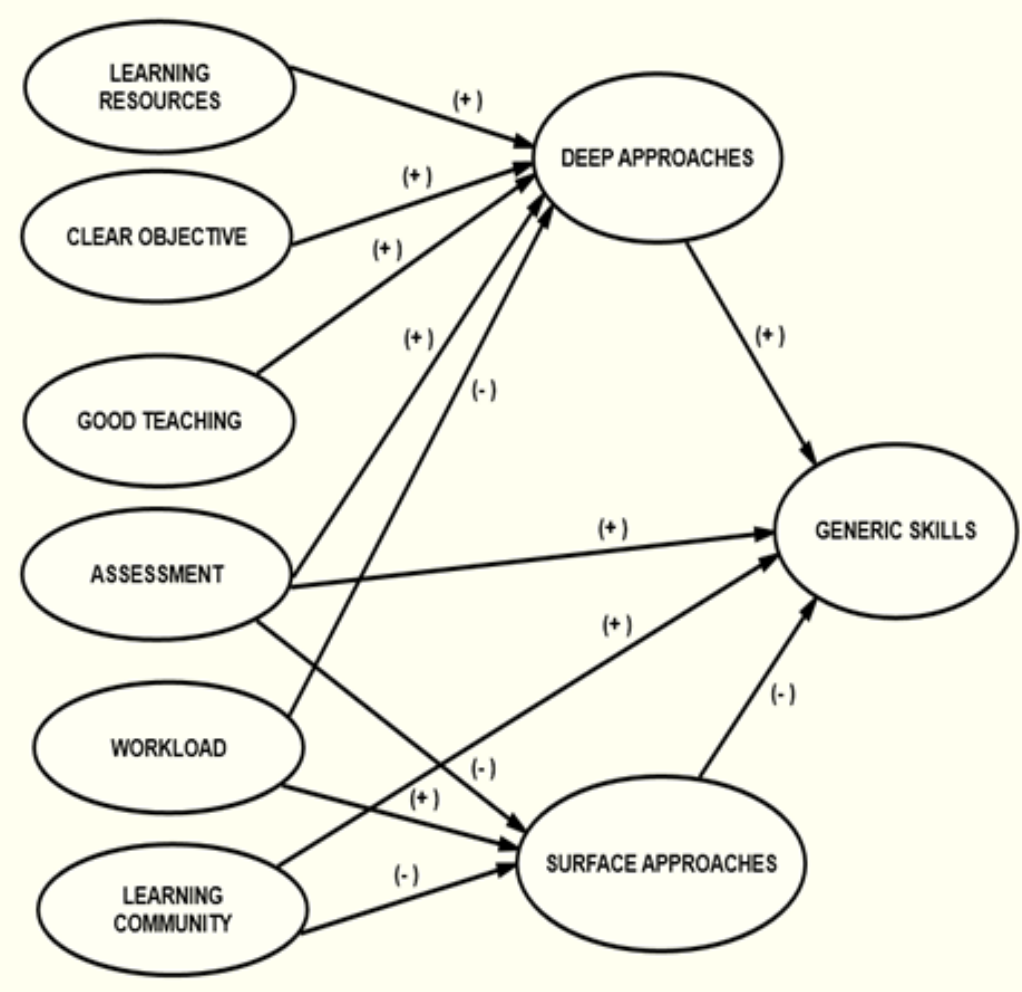

Figure 2. The final model of relationship between learning environment, learning approach, and generic skills

\section{References}

Aida Suraya Md Yunus, Rosini Abu, Sharipah Mohd Nor, Rohani Ahmad Tarmizi, Kamariah Abu Bakar, Wan Zah Wan Ali, Ramlah Hamzah, \& Habsah Ismail. (2005). Generic Skills of Malaysian University Students. Bulletin of Higher Education Research, 6, 5-6.

Anderson, J., \& Gerbing, D. (1988). Structural equation modeling in practice: A review and recommended two-step approach. Psychological Bulletin, 103(3), 411-423. http://dx.doi.org/10.1037/0033-2909.103.3.411

Arbuckle, J. L. (1997). AMOS user's guide version 3.6. Chicago, IL: SmallWater.

Arbuckle, J. L., \& Wothke, W. (1999). AMOS user's guide version 4.0. Chicago, IL: Small Water.

Babbie, E. (1992). The practice of social research. California: Wardsworth Publishing Company.

Bandura, A. (1986). Social foundation of thought and action: A social cognitive theory. Upper Saddle River, NJ: Prentice Hall.

Biggs, J. (1999). Teaching for Quality Learning at University. Birmingham: The Society for Research into Higher Education and Open University Press. http://dx.doi.org/10.1348/000709901158433

Biggs, J., \& Tang, C. (2007). Teaching for Quality Learning at University (3rd ed.). Open University Press: McGrawHill.

Biggs, J., Kember, D., \& Leung, D. Y. P. (2001). The revised two-factor Study Process Questionnaire: R-SPQ-2F. British Journal of Educational Psychology, 71, 133-149.

Bronfenbrenner, U. (1979). The ecology of human development. Cambrigde, Massachusetts: Harvard University Press.

Cabrera, A. F., Colbeck C. L., \& Terenzini P. T. (2001). Developing performance indicators for assessing classroom teaching practices and student learning: The case of engineering. Research in Higher Education, 42(3), 327-352. http://dx.doi.org/10.1023/A:1018874023323

Cohen, J. (1988). Statistical power analysis for the behavioral sources. New York: Academic Press. 
Diseth, A., Pallesen, S., Hovland, A., \& Larsen, S. (2006). Course experience, approaches to learning and $\begin{array}{llll}\text { academic achievement. Education \& } \quad \text { Training, } & \text { 48(2-3), }\end{array}$ http://dx.doi.org/10.1108/00400910610651782

Dorman, J. P. (2003). Cross-national validation of the What Is Happening In this Class? (WIHIC) questionnaire using confirmatory factor analysis. Learning Environments Research: An International Journal, 6, 231-245. http://dx.doi.org/10.1023/A:1027355123577

Entwistle, N. J., \& Ramsden, P. (1983). Understanding student learning. London: Croom-Helm.

Fornell, C., \& Larcker, D. (1981). Evaluating structural equation models with unobserved variable and measurement error. Journal of Marketing Research, 18, 39-50. http://dx.doi.org/10.2307/3151312

Gijbels, D., \& Dochy, F. (2006). Student's assessment preferences and approaches to learning: can formative assessment make a difference? Educational Studies, 32(4), 399-409. http://dx.doi.org/10.1080/03055690600850354

Goh, S. C. (2005). Perceptions of Learning Environment, Learning Approaches and Learning Outcomes. A Study Of Private Higher Institution in Malaysia from Twinning Program. Unpublished Doctoral Theses. University of Adelaide.

Hair, J. F., Anderson, R. E., Tatham, R. L., \& Black, W. C. (2006). Multivariate data analysis. Upper Saddle River, NJ: Prentice Hall.

Kamaruddin Md Tahir. (2010).Penilaian pembangunan kemahiran generik dalam kalangan pelajar tahun akhir Kolej Komuniti Kementerian Pengajian Tinggi. Unpublished Doctoral Theses. Fakulti Pendidikan, Universiti Kebangsaan Malaysia, Bangi.

Karagiannopoulou, E., \& Christodoulides, P. (2005). The impact of Greek University students perceptions of their learning environment on approaches to studying and academic outcomes. International Journal of Educational Research, 43, 329-350. http://dx.doi.org/10.1016/j.ijer.2006.05.002

Kember, D., \& Leung, D. Y. P. (1998). Influences upon students' perceptions of workload. Educational Psychology, 18(3), 293-307. http://dx.doi.org/10.1080/0144341980180303

Kember, D., \& Leung, D. Y. P. (2005). The influence of active learning experiences on the development of graduate capabilities. Studies in Higher Education, 30, 157-172. http://dx.doi.org/10.1080/03075070500043127

Kember, D., Leung, D. Y. P., \& Ma, R. S. F. (2007). Characterising learning environments capable of nurturing generic capabilities in higher education. Research in Higher Education, 48(5), 609-632. http://dx.doi.org/10.1007/s11162-006-9037-0

Kementerian Pengajian Tinggi. (2006). Modul Pembangunan Kemahiran Insaniah (softskills) untuk Institusi Pengajian Tinggi Malaysia. Universiti Putra Malaysia. Serdang.

Lizzio, A, Wilson, K., \& Simons R. (2002). University students perception of the learning environment and academic outcomes: implication for theory and practice. Studies in Higher education, 27(1), 27-52. http://dx.doi.org/10.1080/03075070120099359

Marton, F., \& Säljö, R. (1976). On qualitative differences in learning, outcome and process. British Journal of Educational Psychology, 46, 4-11. http://dx.doi.org/10.1111/j.2044-8279.1976.tb02980.x

McInnis, C., Griffin, P., James, R., \& Coates, H. (2001). Development of the Course Experience Questionnaire $(C E Q)$. Centre for the Study of Higher Education and Assessment Research Centre. Faculty of Education, The University of Melbourne.

Mohamad Sattar, R., Md Yusof, I., Napsiah, I., Muhammad Rashid, R., \& Rose Amnah, A. (2008). Pembangunan Standard Pengukuran Kemahiran 'Employability'. Jurnal Teknologi, 49(E), 15-30.

Noor Dayana Abd Halim. (2010). Students' Perception on the developed generic skills in Universiti Teknologi Malaysia. Paper presented at National conference on students development, UTM; 21-22 Disember 2010.

Norlia, M. N. (2006). Pengaruh input-persekitaran terhadap hasil pembelajaran perspektif pelajar sarjana muda pengurusan perniagaan di IPTA. Unpublished Doctoral Theses. Universiti Kebangsaan Malaysia.

Ramsden, P. (1979). Student Learning and Perceptions of the Academic Environment. Higher Education. Student Learning, 8, 411-427.

Ramsden, P. (1991). A Performance Indicator of Teaching Quality in Higher Education: the Course Experience 
$\begin{array}{lllll}\text { Questionnaire. Studies in Higher } & \text { Education, } & 16, & 129-149 .\end{array}$ http://dx.doi.org/10.1080/03075079112331382944

Ramsden, P. (1992). Learning to Teach in Higher Education. Routledge, London. http://dx.doi.org/10.4324/9780203413937

Ramsden, P., Prosser, M., Trigwell, K., \& Martin, E. (2007). University teachers' experiences of academic leadership and their approaches to teaching. Learning and Instruction, 17, 140-155. http://dx.doi.org/10.1016/j.learninstruc.2007.01.004

Roselina Shakir. (2009). Soft skills at the Malaysian institues of higher learning. Asia Pacific Education Review, 10, 309-315. http://dx.doi.org/10.1007/s12564-009-9038-8

Ruhizan M. Yasin, Saemah Rahman, Ramlee Mustapha, \& Kamarudin Tahir. (2011). Development of generic employability skills through peer interaction and contextual teaching and learning in community college. World Applied Sciences Journal, 15(IPLL), 1-7.

Ryan, M. T., Irwin, J. A., Bannon, F. J., Mulholland, C. W., \& Baird, A. W. (2004). Observations of Veterinary Medicine Students' Approaches to Study in Pre-clinical Years. Journal of Veterinary Medical Education, 31(3), 242-254. http://dx.doi.org/10.3138/jvme.31.3.242

Secretary's Commission on Achieving Necessary Skill. (2001). Skills and Task for Jobs. A SCANS Report for America 2000. Washington, D.C. U.S. Department of Labour Sowell, E.J. (1996). An Interrative Introduction. Englewod Cliffs. Newjersey. Merrill.

Smith, C., \& Bath, D. (2006). The role of learning community in the development of discipline knowledge and generic graduate outcomes. Australia. Higher Education, 51, 259-286. http://dx.doi.org/10.1007/s10734-004-6389-2

The Malaysian Qualifications Agency. (2007). The Malaysian Qualifications Framework. Kuala Lumpur.

Wilson, K. L., Lizzio, A., \& Ramsden, P. (1997). The development, validation and application of the Course Experience Questionnaire. Studies in Higher Education, 22(1), 33-53. http://dx.doi.org/10.1080/03075079712331381121 